\title{
Effect of Constituency Development Fund on Socio-economic Development in Mbeere South Constituency, Kenya
}

\author{
David Muriuki Ngiri, Wycliffe Misuko Nyaribo \\ School of Business and Public Management, KCA University, Nairobi, Kenya \\ Email address: \\ davidmngiri@gmail.com (D. M. Ngiri), drnyaribo@kca.ac.ke (W. M. Nyaribo) \\ To cite this article: \\ David Muriuki Ngiri, Wycliffe Misuko Nyaribo. Effect of Constituency Development Fund on Socio-economic Development in Mbeere \\ South Constituency, Kenya. International Journal of Economics, Finance and Management Sciences. Vol. 4, No. 4, 2016 , pp. 182-189. \\ doi: $10.11648 /$ j.ijefm.20160404.13
}

Received: June 16, 2016; Accepted: June 28, 2016; Published: July 21, 2016

\begin{abstract}
The purpose of this study was to find out the effect of Constituency Development Fund on socio-economic development in Mbeere South Constituency of Embu County, Kenya. A quantitative descriptive design was adopted, whereby cluster sampling method was used according to five administrative wards in Mbeere South, Kenya. Convenience sampling method was adopted to pick a sample of 100 respondents from across the five administrative wards. The instrument that was used for data collection was a questionnaire. A step-wise regression was used on each independent variable against the dependent variable, with a final multivariate regression model to determine the relative importance of each of the three independent variables with respect to effect of Constituency Development Fund projects on socio-economic development and established that all the three independent variables have a positive correlation with the dependent variable. The ANOVA was meant to investigate if variation in the independent variables explained the observed variance in the outcome, which in this case was the local development. The ANOVA results of the study showed a correlation between the predictor variables and the response variable, meaning that there was a strong positive relationship between the study variables.
\end{abstract}

Keywords: Socio-economic Development, Devolution, Civic Culture, Stakeholder Participation

\section{Introduction}

Extreme poverty is currently a major challenge, both in the developing and under developed economies across the globe (Olinto andUematsu, 2000). Poverty affectsmany people in different ways thought the world. In most cases majority of poor people reside developing countries and face many unsurmountable social economic challenges. To address poverty, there is need to have sustainable development inorder meet the basic needs so as to fulfill the aspirations for a better life.

Development in most developing economies has been adversely affected and the effect ispredominantly felt in core institutions of the society in sectors such as health and education (Auya andOino, 2013). According to the International Institute for Sustainable Development (IISD, 2013), for sustainable development to be realized, the needs of the present must be met without compromising the ability of future generations to meet their own needs. The best way to eradicate poverty and achieve sustainable development, working with poor community members should be the core strategy for any sustainable socio-economic development to be achieved (IISD, 2013).

\subsection{Socio-economic Development}

The term socio-economic development is today a household term in the whole world and has become a component of mainstream thinking. It is geared towards increase in productivity, creation of jobs and wealth, human capacity building, promotion of entrepreneurship, and improvement of income levels at the household levels (OECD, 2007). Socio-economic development is today viewed as the approach that will help in improving quality of life, while at the same time supporting empowerment of the ordinary person, develop and preserve the local assets, overcome market failures, and strengthening of cohesive 
projects that deliver the grass-root development projects. According to Jouen et al. (2010), such initiatives are usually area-based integrated strategies aimed at mobilizing a certain number of local stakeholders. This therefore underscores the important role of decentralization in socio-economic development in rural areas.

\subsection{Constituency Development Fund}

The Constituency Development Funds (CDF) has been ongoing in many developing economies around the world for many years. Chambers (2004), notes that in the Philippines, the use of Central Government funds by the MPs for local projects in their areas of jurisdiction goes back to 1930. This was copied from the politics of the United States of America, which became a benchmark for design of a CDF that was launched way back in 1989. Papua New Guinea also embraced the CDF mechanism in 1984, and eventually this innovation became a common Government budgetary allocation mechanism in the developing economies in Asia and Africa.

Aduda (2008) opines that CDF is meant to give the people at the local levels the chance to make informed expenditure decisions that are geared to maximizing their welfare. Most of these development projects are in education, health, economic empowerment as well as infrastructure developments, which are the main challenges facing community development since independence (Kimenyi, 2005). Other areas of intervention by the Fund are rural roads, water and sanitation, police posts and cattle dips among others.

Constituency development fund in Kenya wasinitiated in 2003, the Government introduced CDF with an objective of taking development closer to the beneficiaries by empowering them through project management processes. The Fund is a decentralized National Government budgetary allocation initiative which is meant to ensure that at least a sizeable percentage of the National budget trickles down to the jurisdictions of the members of Parliament (Tsubura, 2013). This helps in financing of local and small-scale development project such as the building of health centers, schools, as well as water supply systems, among other key projects. Tsubura, (2013), notes that CDF is an innovation by the Government whereby the local Members of Parliament (MP) is given the authority to decide the criteria of selection of local development projects under his jurisdiction. Baskin, (2010), also notes that a CDF is not only a channel of funds from the central government to the Local government, but also a strategic tool meant for re-distributive game by the MPs during election. It therefore means that CDFs are not free from political patronage by the MPs. This is because according to Baskin (2010), these same MPs do use the funds to respond to the development needs of their constituents, they also cultivate their own personal votes that enhance their chances of their re-election.

Since Kenyanindependence in 1963, the government has attempted to establish many decentralization development strategies aimed at uplifting the standards of living of its citizens. These strategies included the Majimbo (devolved) system of 1963, the District Development Grant Plan of 1966, and the Special Rural Development Program of 1970. Others included the District Development Planning of 1971, the Rural Development Fund of Kenya in 1983, and the District Focus for Rural Development of 1984, among others, Auya and Oino (2013). It is noteworthy that most of these strategic initiatives failed in their efforts to bring development closer to the citizens due to inefficiencies of line ministries, technical incompetency, and lack of staff, as well as bureaucracies in implementation, (Auya andOino, 2013). Other bottlenecks included poor financing arrangements characterized by delays in as far as releasing of funds are concerned. Various research efforts have been done on the contributions of the Constituency Development Fund on local development in Kenya albeit with mixed signals.

A study conducted by Kimenyi (2005) on efficiency of Constituency Development Fund in social development, established that the CDF is indeed desirable. However, the study notedthat CDF projects were sometimes based on political affiliations, were not designed professionally, and that in some cases the projects ended up as white elephants. In a similar study that was conducted by Mapesa andKibua (2006), whereby a sample of five constituencies was used to test levels of beneficiary awareness and participation, institutional capacity, coordination and legal framework of the fund, concluded that the fund belonged to the local members of parliament, and therefore the beneficiaries were not aware of their rights to full participation and monitoring. The study especially noted that the funds were being spent without due diligence as far as planning, selection and implementation were concerned.

The challenges that face CDF in Kenya therefore attract the question of the extent to which the fund is meeting its intended purpose of local development through beneficiary involvement. This therefore informed the need to conduct a study on the effect of CDF in Mbeere South Constituency in Embu County in Kenya, to find out the contribution of CDF on local community development, as a case of how the fund is impacting on development in Kenya.

\subsection{Objectives of Study}

This study was guided by the following objectives

I. To find out the extent to which the infrastructure projects by the CDF have improved socio-economic development.

II. To find out the extent to which the social welfare projects by the CDF have improved socio-economic development.

III. To find out the extent to which the Job creation initiatives by the CDF have improved socio-economic development.

\section{Literature Review}

Socio-economic development is a concept whereby the development stakeholders envision helping in improving 
quality of life, to support empowerment of the local ordinary people, to develop or preserve the local assets, to overcome market failures, to strengthen cohesion, and to define and deliver grass-root development projects. The initiatives touted in such a direction are usually area-specific integrated strategies that help to mobilize a big number of local stakeholders (Jouen, 2010). This means that decentralization is an important tool to achieve socio-economic development.

According to Botchie, (2000), the three major sources of financing for local development include transfers from the Central Government, donor funding and the internally generated funds. Todaro and Smith (2012), assert that development is the capacity and the ability of an economy, which has been having a static initial economic condition for a considerable period of time to start generating and sustaining a yearly increase of its GDP at rates between $5 \%$ to $7 \%$ or more.

According to Todaro and Smith (2012), socio-economic development is aimed at changing popular attitudes, social structures, as well as national structures across the social divide. It is also aimed at accelerating economic growth, while at the same time reducing inequality, and eradication of poverty. Chigbu, (2012), also notes that local development actions are usually geared towards developing a social and economic development pattern of the targeted area. Socioeconomic development also aims at finding solutions that are geared towards improving the lives of the rural poor, and increasing their participation.

Decentralization is today an engine through which local development is being achieved since the past two decades. Local governments are increasingly being charged with the responsibility to plan, implement and finance local development activities in their local jurisdictions. It is however noted that the financing tools that these local governments adopt for local development vary among countries (OECD, 2007). Most of the developed countries use tax credits and incentives, as well subsidies and regulations to induce local development. They may also issue public bonds towards the support of activities that in other countries are the preserve of private fund managers (OECD, 2007). In developing countries however, local governments depend on Central Governments and donors to finance local development efforts (Litschig, 2010, Kuntajar, 2006; Botchie, 2000). For instance in Brazil, government grants alone account for up to 50 percent of Local Government revenues for financing local developments (Litschig, 2010). Moreover in Uganda, Local Governments finance only up to 10 percent of their budgets from local sources, while most of the Local Government income in Tanzania comes from Central Government allocations, which account for $72 \%$ of the entire local authority budget (Kuntajar, 2006).

Infrastructure is a set of various physical facilities which serve as media for the provision of public goods and services. It is the basic stock of capital that is required by an economy so as for that economy to be able to offer goods and services to its citizen. Infrastructure includes public works like roads and railway lines, electricity and water lines, airports, buildings, and many more (Srinivasu andRao, 2013).

The success of the East Asian Tigers has been attributed to heavy investments in labor intensive manufacturing. This has in effect generated sufficient employment to the populations, thereby helping to reduce poverty (Melamed et. al, 2011). Other sectors that impact positively in alleviation of poverty may include agriculture and construction sectors (Loayza andRaddatz, 2010). However, the effectiveness of different sectors in different economies in generating employment do change over time. Khan (2007), notes that growth in some Asian economies is now less effective in the generation of employment than it used to be some years back. This shows that low-wage employment creation has only short term benefits. During the financial crisis of 2008, Robert Zoellick, the president of the World Bank noted that the best safety net for any people is a job (Melamed et. al 2011). They also noted that free movement of people between different sectors of the local economy would give people best protection against risks.

\section{Methodology}

The study employed a survey design which is frequently used in studying attitudes, opinions, preferences and perceptions of people. The survey design collected data from members of a population in order to determine the correct status of that population. Cluster sampling procedure was adopted in the entire Constituency through its five wards. This study then used the formula as proposed by Yamane (1967) for a large but finite population, at 95\% confidence level and $10 \%$ degree of precision to come up with a samplesize ofone hundred respondents from the entire population. Data was collected through self-administered questionnaire. Cronbach Alpha was employed to test reliability, and showed an alpha value of more than 0.7 which is acceptable. Data was analyzed using regression analysis.

The effect of CDF projects on local development was determined by:

Formula (1), $Y=\alpha+\beta_{1} X_{1}+\beta_{2} X_{2}+\beta_{3} X_{3}+\varepsilon$

Where:

$\mathrm{Y}=$ Social-economic Development

$\alpha=$ Constant/the intercept point of the regression line and the $y$-axis

$\beta=$ the slopes/gradients of the regression line

$\mathrm{X}_{1}=$ Infrastructural projects, $\mathrm{X}_{2}=$ Social welfare projects

$\mathrm{X}_{3}=$ Job creation projects

$\varepsilon=$ Error term

Socio-economic Development $=\alpha+\beta_{1}$ (Infrastructure Projects) $+\beta_{2}$ (Social Welfare Projects) $+\beta_{3}$ (Job Creation Projects $)+\varepsilon$. Therefore;

Formula (2), SED $=\alpha+\beta_{1} \mathrm{IP}+\beta_{2} \mathrm{SWP}+\beta_{3} \mathrm{JCP}+\varepsilon$

The strength of the relationship between the dependent and the independent variables was measured by carrying out correlation tests at $5 \%$ level of significance and $95 \%$ level of confidence. The tests determined whether the coefficients $\beta_{1}$, $\beta_{2}$, and $\beta_{3}$ were significantly positively correlated with the dependent variable, and vice versa. This in turn facilitated 
thesummation of items and the detection of errors and omissions. The data was analyzed with the help of STATA statistical package

\section{Analysis}

Out of the 100 respondents reached out, all the 100 questionnaires were fully completed and returned. This gave a response rate of $100 \%$. A fairly even distribution of respondents from each of the five wards was sampled with Kiambeere and Makima having 22\% each and Mbeti South having 20\%. From Mavuria and Mwea, the respondents counted for $18.0 \%$ of the total population respectively.

\subsection{Correlation Analysis of Infrastructure Projects on Socio-economic Development}

In establishing the relationship of the test items, a Cronbach alpha reliability test was conducted on the 8 items. The result showed a reliability of 0.8861 indicating that the findings were consistent and reliable. Pearson product moment correlation analysis was computed on the respective infrastructure project items on CDF project overall effect on local development.

Table 1. Linearity between Infrastructure Projects and Socio-economic Development.

\begin{tabular}{|c|c|c|}
\hline \multirow[b]{2}{*}{ Statement on Infrastructure Projects in the Community } & \multicolumn{2}{|c|}{ Socio-economic Development } \\
\hline & r-value & P-value \\
\hline CDF has implemented and expanded educational facilities and infrastructure & $0.432 * *$ & 0.000 \\
\hline CDF has improved development through educational facility projects & $0.453 * *$ & 0.000 \\
\hline CDF has implemented and expanded health facilities and infrastructure & $0.409 * *$ & 0.000 \\
\hline CDF has improved development through health facilities and infrastructure projects & $0.447 * *$ & 0.000 \\
\hline CDF has implemented water and electricity connection projects & $0.323 * *$ & 0.000 \\
\hline CDF has improved development through water and electricity connection project & $0.449 * *$ & 0.000 \\
\hline CDF has built access roads and bridges & $0.457 * *$ & 0.000 \\
\hline CDF has improved local development through roads and bridge construction projects & $0.456 * *$ & 0.000 \\
\hline
\end{tabular}

${ }^{* *}$ Indicate that correlation is significant at $\mathrm{P}=0.0000, \mathrm{r}$-correlation value, calculated probability value at $95 \%$ Confidence Interval.

Results from this analysis showed that infrastructure development projects by CDF were significantly positively effective on local development $(\mathrm{r}=0.570, \mathrm{P}=0.000)$ in the Constituency. The respondents' agreement on the infrastructure effects on development attributed and consequently agreed that CDF projects affect socio-economic development.

\subsection{Regression of CDF Infrastructure Projects on Socio-economic Development}

Using a linear regression analysis of the CDF infrastructure projects local development, the major effective items on socio-economic development was improved development through water and electricity connections projects in the community $R^{2}$ value of 0.3247 with a standardized beta value of 0.5698 .

Therefore this was an indication that infrastructure projects were significant in enhancing socio-economic development at $56.89 \%$ other things held constant.

To establish the relationship of the test items on social welfare, a Cronbach alpha reliability test was conducted on the 6 items.

Table 2. Relationship between Social Welfare Projects and Socio-economic Development.

\begin{tabular}{|c|c|c|}
\hline \multirow[b]{2}{*}{ Statement on Social Welfare Projects } & \multicolumn{2}{|c|}{ Effect on Socio-economic Development } \\
\hline & r-value & P-value \\
\hline CDF has given out bursaries to needy students in this community & $0.465 * *$ & 0.0001 \\
\hline CDF has improved development through bursaries to needy students in this community & $0.559 * *$ & 0.0001 \\
\hline CDF has implemented projects that promote basic health and nutrition & $0.614 * *$ & 0.0001 \\
\hline The health and nutrition projects facilitated by the CDF improveddevelopment & $0.497 * *$ & 0.0001 \\
\hline CDF has implemented security improvement projects & $0.392 * *$ & 0.0001 \\
\hline The security projects facilitated by CDF has improved development & $0.458 * *$ & 0.0001 \\
\hline
\end{tabular}

${ }^{* *}$ Indicate that correlation is significant at $\mathrm{P}=0.01$, r-correlation value, calculated Probability value at $95 \% \mathrm{CI}$.

The result showed a reliability of 0.8384 indicating that the findings were consistent and reliable.

Pearson product moment correlation analysis was computed on the respective social welfare project items on CDF project overall effect on local development. The overall effect of CDF project on socio-economic development was significantly affected by the social welfare projects in the Constituency. The respondents' agreement on the social welfare effects on development significantly $(\mathrm{r}=0.655, \mathrm{P}=$ 0.0000) agreed that CDF projects affect socio-economic development positively.

\subsection{Regression Analysis of Social Welfare Projects on Socio-economic Development}

Result based on a linear regression analysis on the social welfare items on the effect of CDF on socio-economic development showed that the major effective items on the overall effect of CDF on socio-economic development was that the CDF has improved development through bursaries to 
needy students and the CDF has implemented projects that promote basic health and nutrition in this community, $\mathrm{R}^{2}$ value of 0.4292 with a standardized beta value of 0.6551 .

Since the standardized beta coefficient for social welfare projects against local development was 0.6551 , this meant that change in $\mathrm{Y}$ due to change in $\mathrm{X}_{2}$ was 0.5698 , all other things held constant. Therefore this was an indication that social welfare projects were significant in enhancing socioeconomicdevelopment at $65.51 \%$ whileothersbeingconstant.

\section{Job Creation Projects on Socio-Economic Development}

To establish the relationship of the test items on socioeconomic development, a Cronbach alpha reliability test was conducted on the 6 items. The result showed a reliability of 0.8517 indicating that the findings were consistent and reliable. Pearson product moment correlation analysis was computed on the respective job creation project items on CDF project overall effect on socio-economic development.

Table 3. Respondents Opinion on Job Creation Projects and Socio-economic Development.

\begin{tabular}{l|l}
\hline & Effect of CDF on Socio-economic Development \\
\hline Statements on Job Creation in the Community & r-value \\
CDF has implemented business and entrepreneurship development projects & $0.388^{* *}$ \\
The business and entrepreneurship projects facilitated by the CDF have improved development & $0.422^{* *}$ \\
$\begin{array}{l}\text { CDF has a awarded tenders for supply of materials for its projects to residents } \\
\text { The award of tenders for supply of materials for CDF projects to residents of this area has improved } \\
\text { development }\end{array}$ & $0.506^{* *}$ \\
$\begin{array}{l}\text { The CDF has offered direct employment opportunities to members } \\
\text { The employment creation by CDF through direct employment has improved development }\end{array}$ & 0.0001 \\
\hline
\end{tabular}

${ }^{* *}$ Indicates a significant at $\mathrm{p}=0.01, \mathrm{r}$-correlation value, calculated Probability value at $95 \%$ Confidence Interval.

Socio-economic development was significantly affected by job creation projects in the Constituency. The respondents who noted that there were effects of job creation significantly $(\mathrm{r}=0.5045, \mathrm{P}=0.0000)$ agreed that $\mathrm{CDF}$ projects affect socio-economic development positively.

\subsection{Regression Analysis of Job Creation on Socio-economic Development}

The results based on a linear regression analysis on job creationitems on the effect of CDF on socio-economic development showed that the major items on the overall effect of CDF on socio-economic development was that the CDF has offered direct employment opportunities to citizens for improved development. The award of tenders for supply of materials for CDF projects to residents of this area has improved development and the business and entrepreneurship projects facilitated by the CDF have improved development in this community, with a $\mathrm{R}^{2}$ value of 0.4807 and a standardized beta value of 0.6933 .

Since the standardized beta value for job creation projects against socio-economic development was 0.6933 , this meant that change in $\mathrm{Y}$ due to change in $\mathrm{X}_{3}$ was 0.6933 , all other things held constant. Therefore this was an indication that social welfareprojects were significant in enhancing socioeconomic development at $69.33 \%$ other things held constant.

\subsection{Summarized Pre-regression Testing for Linearity}

The data was pre-tested for linearity before the regression was performed. The results indicated overall strong positive linear relationships between the variables.

Table 4. Summarized Pre-regression Testing for Linearity.

\begin{tabular}{|c|c|c|c|c|}
\hline Variable & $\begin{array}{l}\text { Correlation coefficient with } \\
\text { socio-economic development }\end{array}$ & $\begin{array}{l}\text { Correlation coefficient with } \\
\text { Infrastructure projects }\end{array}$ & $\begin{array}{l}\text { Correlation coefficient with } \\
\text { Social welfare projects }\end{array}$ & $\begin{array}{l}\text { Correlation coefficient } \\
\text { with Job creation projects }\end{array}$ \\
\hline $\begin{array}{l}\text { Socio-economic } \\
\text { Development }\end{array}$ & 1.000 & 0.5698 & 0.6551 & 0.6933 \\
\hline Infrastructure Projects & 0.5698 & 1.000 & 0.7359 & 0.5670 \\
\hline Social Welfare Projects & 0.6551 & 0.7359 & 1.000 & 0.6501 \\
\hline Job creation projects & 0.6933 & 0.5670 & 0.6501 & 1.000 \\
\hline
\end{tabular}

Table 3.4 shows that all the variables were significantly positively linearly related. Infrastructure projects showed a $56.98 \%$ linear relationship with socio-economic development, while social welfare and job creation projects projected $65.51 \%$ and $69.33 \%$ linear relationship with local development respectively. Social welfare projects and job creation projects showed $73.59 \%$ and $56.70 \%$ linear relationships with infrastructure projects respectively; while job creation projects showed a $65.01 \%$ linear relationship with social welfare projects. This meant that all the variables were well linearly related as per table 16 above.

\subsection{Summary of Regression Results}

When considering the effects of the Infrastructure, social welfare and job creation, using a stepwise linear regression, the test model was therefore:

Formula (3), $Y=\beta+X_{1}+X_{2}+X_{3}+\varepsilon$

Where $\mathrm{Y}$ was Socio-economic development,

$\beta$ was the constant, $X_{1}$ was Infrastructure projects, $X_{2}$ was Social welfare projects,

$\mathrm{X}_{3}$ was Job creation projects, $\varepsilon$ was the error term.

The effects of the Infrastructure, social welfare and job creation for analysis of the linear regression on socio- 
economic development showed a regression $\mathrm{R}^{2}$ value of 0.5579 . This indicated a $55.79 \%$ of the points on the line of best fit. When testing the three items (infrastructure, social welfare and job creation) against the overall effect of CDF on local development, computation revealed that the effect of infrastructure $(\mathrm{t}=1.02, \mathrm{P}=0.308)$ was not significant in the presence of the effect of social welfare $(\mathrm{t}=2.59, \mathrm{P}=0.011)$ and job creation $(\mathrm{t}=4.91, \mathrm{P}=0.0001)$. Using standardized beta coefficients, the model therefore becomes:

Therefore socio-economic development is equal to:-

Formula $(4),(\mathrm{Y})=0.8179+0.1048$ (infrastructure projects) +0.2873 (social welfare projects) +0.4471 (job creation projects).

This is summarized in table 5 .

Table 5. Model Table for the CDF Projects Effect on Socio-economic Development.

\begin{tabular}{|c|c|c|c|c|c|}
\hline \multirow{2}{*}{ Model Variables } & \multicolumn{2}{|c|}{ Un-standardizedcoefficients } & \multirow{2}{*}{$\begin{array}{l}\text { Standardized Coefficients } \\
\text { Beta }\end{array}$} & \multirow{2}{*}{ t-statistic } & \multirow{2}{*}{ Significance } \\
\hline & Beta & Robust Standard errors & & & \\
\hline Constant & 0.8179 & 0.9306 & & 0.88 & 0.382 \\
\hline Infrastructure Projects & 0.0632 & 0.0782 & 0.1048 & 0.81 & 0.421 \\
\hline Social Welfare projects & 0.2378 & 0.1002 & 0.2873 & 2.37 & 0.020 \\
\hline Job creation projects & 0.3254 & 0.0793 & 0.4471 & 4.10 & 0.000 \\
\hline
\end{tabular}

The regression coefficients result indicated that in Mbeere South Constituency, the residents mainly considered the effect of CDF projects on job creation and social welfare projects as indicators of CDF's contribution on development on local community. Some of the positive effects of CDF on the local community Development, according to the respondents were, creation of jobs to locals which has in turn improved their living standards, eradicating diseases and improved water supply in the area, improve diet through irrigated crops, motivation of disabled students, improved literacy levels in schools, and fair share of resources and support the sick. Some of the negative effects were corruption when implementing projects, Executives rotating themselves in their seats, and poor communication.

\section{Summary}

Going by step-wise correlation analysis, CDF infrastructure development projects had significantly $(\mathrm{r}=0.5698, \mathrm{P}=$ 0.0000) positively affected local development in the Constituency. The respondents' agreement on the infrastructure effects on development attributed and consequently agreed that CDF projects affect local development. The findings in this study showed that in this Constituency, the CDF has mainly implemented and expanded educational facilities and infrastructure (mean response 3.88) and it has improved development through educational facility projects in the community (mean response 3.68 ) in the Likert's scale of $1-5$. The least effect of the CDF was the building of access roads and bridges as indicated by mean response of 2.60 and improved local development through roads and bridge construction projects (mean 2.63). This indicated that roads and bridges construction were not CDF project priorities in this Constituency.

However on the overall, infrastructure projects showed lack of significance $(\mathrm{P}>|\mathrm{t}|=0.421)$ at $5 \%$ level, and therefore did not contribute to socio-economic development in the Constituency, with only a $6.32 \%$ observed variation in improvement of socio-economic development conditions if a one per cent change in infrastructure budgetary allocation was effected. The standardized beta score was however at
$10.48 \%$, being change in socio-economic development due to a unit change in infrastructure projects.

Using step-wise correlation analysis on the effect of social welfare projects by CDF on socio-economic development, it was noted that these projects significantly affected socioeconomic development in the Constituency. The respondents' agreement on the social welfare effects on development significantly $(\mathrm{r}=0.6551, \mathrm{P}=0.0000)$ agreed that $\mathrm{CDF}$ projects affect socio-economic development positively.

However on the overall, social welfare projects showed some significance of $(\mathrm{P}>|\mathrm{t}|=0.020)$ at $5 \%$ level, and therefore it was noted that these contributed significantly to socio-economic development in the Constituency, with some $23.78 \%$ observed variation in improvement of socioeconomic development conditions if a one per cent change in social welfare budgetary allocation was effected.

Socio-economic development was also significantly affected by job creation projects in the Constituency. The respondents who noted that there were effects of job creation significantly $(\mathrm{r}=0.693, \mathrm{P}=0.000)$ agreed that $\mathrm{CDF}$ projects affect socio-economic development positively. The reliability for job creation projects posted a score of 0.8517 , indicating that the findings were consistent and reliable. Pearson product moment correlation analysis was computed on the respective job creation project items on CDF project overall effect on socio-economic development showed that local development was significantly affected by job creation projects in the Constituency. The respondents who noted that there were effects of job creation significantly $(r=0.5045, P$ $=0.0000)$ agreed that $\mathrm{CDF}$ projects affect socio-economic development positively.

Step-wise regression results posted a $R^{2}$ value of 0.4807 and a standardized beta value of 0.6933 . This was an indication that social welfareprojects were significant in enhancing socio-economic development at $69.33 \%$ other things held constant. However when the final regression was done, job creation projects posted a standardized beta value of 0.4471 , this being the change in socio-economic development due to one unit change in implementation of job creation projects. It also posted a P-value of 0.000 , which meant significance at 5\% level. 


\section{Conclusions, Recommendations and Suggestion for Further Studies}

\subsection{Conclusions}

The model was found to be well fitted with an F-test statistic of 0.0000 , and R-squared of 0.5579 . The study found that CDF in Kenya has impacted on socio-economic development with an adjusted R-squared of 0.544 . The model therefore fitted the variables significantly at 5 per cent level. Put together, this meant that the independent variables of this study contributed $55.79 \%$ to socioeconomic development in the constituency, with the remaining $44.21 \%$ being explained by other variables not included in this study.

The results of this study also indicated that education bursaries and direct employment interventions took the lead in effecting development with mean responses of 4.12 and 3.88 respectively. However on the overall, a variation of one percent in budgetary allocations by CDF for any of the three independent variables of job creation projects, social welfare projects and infrastructure development projects respectively, a significant level of improvement in socio-economic development would be evident at five per cent level. In order importance, job creation would contribute to socio-economic development with by $32.5 \%$ while social welfare would contribute by respectively. In the overall regression equation, infrastructure projects did not have significant contribution to local development in Mbeere South Constituency with a contribution of $6.3 \%$.

\subsection{Recommendations}

The study results showed that job creation projects by $\mathrm{CDF}$ influenced socio-economic development. This means that for a sustainable development, policy makers and development actors should allocate more funds for Kenya to invest more in sectors that create employment for acceleration of socio-economic development. The study also noted that social welfare projects influence local development to a good extent. According to OECD (2011), both education and health are the most basic pre-requisites for sustainable development for the emerging economies. This study therefore recommended some key policy issues for long term sustainable local development. More efforts should be made by CDF to invest in social welfare and creation of jobs for more acceleration of development. The Central Government should come up with policies that ensure that social welfare and job creation are adequately allocated at devolved levels for acceleration of socioeconomic development in Kenya. The Central government should also bring in other development partners including INGOs and Faith-based Organizations to a common approach and prioritize their efforts in job creation and social welfare projects so as to complement the Government efforts for acceleration of socio-economic development.

\subsection{Suggestion for Further Studies}

This study was limited to the effect of the Constituency Development fund on socio-economic development in Mbeere South Constituency. It mainly focused on infrastructure, social welfare and job creation. The results of the study showed that although the CDF had invested a lot in infrastructure projects, with $88.96 \%$ of its $2010 / 2011$ annual budgetary allocation going infrastructure (NTA, 2012), these projects did not influence local development significantly with a standardized beta coefficient of 0.1048 with 1 per cent increase in budgetary allocation. This study recommends further research to gather more information on why the infrastructure projects by CDF are not significant in effecting local development in Kenya.

More research is also needed to find out what other key independent variables other than the ones included in this study that could be accounting to the $44.21 \%$ of local development through CDF interventions in Kenya.

\section{References}

[1] Aduda, A. 2008. Implementation of Free Secondary Education in Kenya, Nairobi: Nairobi University press.

[2] Auya S. \& Oino, P. 2013. The Role of Constituency Development Fund in Rural Development: Experiences from North Mugirango Constituency, Kenya: International Journal of Science and Research (IJSR), India Online ISSN: 23197064 .

[3] Baskin, Mark. 2010. 'CDFs American Style: Distributive Policy and Member Items in New York State': Summary Paper; SUNY Center for International Development. Rockefeller College of Public Affairs and Policy University at Albany, State University of New York New York, 20-21 May 2010.

www.cid.suny.edu/publications 1/CDFs\%20American\%20Styl e.pdf. (accessed June 4, 2015)

[4] Botchie, G. 2000. Local Strategic Planning and Sustainable Rural Livelihoods Rural District Planning in Ghana: A Case Study. Environmental Planning Issues No. 21, International Institute for Environment and Development. London. United Kingdom.

[5] Chigbu, U. E. 2012. Village Renewal as an Instrument of Rural Development: Evidence from Weyarn Germany. Community Development, Vol. 43 (2): 209-224.

[6] Jouen, et al. 2010. Cohesion Policy Support for Local Development: Best Practice and Future Policy Options. Final Report, European Union.

[7] Khan, A. 2007. Growth, employment and Poverty: An analysis of the nexus based on some recent UNDP and ILO/SIDA studies; DESA working paper No. 49. New York: UN-DESA.

[8] Kimenyi, Mwangi S,. 2005. Efficiency \& Efficacy of Kenya's Constituency Development Fund. Theory and Effidence: Economics Working Papers. Available online from URL: http://digitalcommons.uconn.ed/econ_wpapers/200542.

[9] Kuntajar J. 2006. Local Government System in Tanzania. 
[10] Litschig S. 2010. Financing Local Development: QuasiExperimental Evidence from Municipalities in Brazil, 19801991. Department of Economics and Business. Universitat Pompeu Fabra.

[11] Mapesa, B. M., and Kibua, T. N,. 2006. An Assessment of the Management and theUtilization of the Constituency Development Fund in Kenya: Institute of Policy Analysis and Research, Discussion Paper Series No. 086/2006. Nairobi. Jomo Kenyatta Foundation.

[12] Melamed et. al. 2011. Jobs, growth and poverty: What do we know, what don't we know, what should we know? Overseas development institute. Available: www.odi.org.uk.

[13] OECD. 2007. Financing Local Development. Policy Brief: Organization for Economic Co-Operation and Development.

[14] Olinto P., \& Uematsu, H. 2010. The State of the Poor: Where are the Poor and where are the Poorest.: Poverty Reduction and Equity Department. World Bank.
[15] Srinivasu, B. and Rao, S. 2013. Infrastructure Development and Economic growth: Prospects and perspective: Journal of Business Management and Social Sciences Research; Vol. no 1. Available: www.borjournal.com

[16] Todaro, M. P., and Smith, S. C. 2012. Economic Development. ( $11^{\text {th }}$ edition). New York; Addison-Wesley.

[17] Todaro, M. P., 1981."Economic Development in the Third World". ( $2^{\text {nd }}$ Edition). Longman. New York.

[18] Tsubura M. 2013. The Politics of Constituency Development Funds (CDFs) in Comparative Perspective: Institute of Development studies, University of Sussex.

[19] Yamane, Taro. 1967. Statistics: An introductory Analysis. (2 ${ }^{\text {nd }}$ Ed.). New York: Harper and Row.

[20] Zependa, E. 2007. Addressing the employment -poverty nexus in Kenya: Comparing cash-transfer and job creation Programmes: Working paper No. 40. Brasilia: IPC-UNDP. 